\title{
Real Time System for Indonesian Teacher Engagement Index Application
}

\author{
Sasmoko ${ }^{1}$, Yasinta Indriati ${ }^{2}$, Desi Maya Kristin ${ }^{3}$, Brilly Andro Makalew ${ }^{3}$, Yogi Udjaja ${ }^{4}$, \\ Abu Yazid Abu Bakar ${ }^{*}$
}

\begin{abstract}
${ }^{1}$ Primary Teacher Education Department, Faculty of Humanities, Bina Nusantara University, Jakarta, Indonesia, 11480
${ }^{2}$ Research Interest Group in Educational Technology, Bina Nusantara University, Jakarta, Indonesia 11480

${ }^{3}$ Information System Department, School of Information System, Bina Nusantara University, Jakarta, Indonesia 11480

${ }^{4}$ Computer Science Department, School of Computer Science, Bina Nusantara University, Jakarta, Indonesia 11480

${ }^{5}$ Faculty of Education, Universiti Kebangsaan Malaysia, 43600 Bangi, Selangor, Malaysia

*Corresponding author. Email: yazid3338@ukm.edu.my5
\end{abstract}

\begin{abstract}
Technological developments in education must have a positive impact on improving teacher quality and competence in Indonesia so that teachers are able to run their profession optimally. When teachers are able to play an optimal role then the teacher will provide a significant added value for improving the quality of education in Indonesia. The Indonesian Teacher Engagement Index application was developed to capture the teacher's need for self-assessment. And to improve this application then ITEI Apps created one scheme using real time system. The research method used is exploratory research. The result of the research is real time system design which is an additional scheme as an effort to continue to maximize the value and function of this application for the teacher as the user.
\end{abstract}

Keywords: Real time system, Indonesian teacher engagement index, neuroresearch, expert system, mobile apps

\section{INTRODUCTION}

The Indonesian Teacher Engagement Index (ITEI) is a concept developed specifically to assist teachers in assessing themselves in relation to the conditions of engagement that have been adapted to the Indonesian context. The complex and diverse tasks of the teachers themselves demand that the teacher not only focus and have an extraordinary spirit in teaching, but there are many other factors that will help the teacher to be more optimal in carrying out his or her whole profession. This is the basis for the development of the concept of Indonesian Teacher Engagement because it is the integration of the concept of teacher engagement and the characteristics of Indonesian teachers are diverse but have the same value (Sasmoko et al., 2017; Sasmoko et al. 2018).

By leveraging the latest technological advances, ITEI has been developed in the form of android applications that can be accessed by all teachers in Indonesia wherever they are and whenever (Manalu et al. 2018). This application was developed with the aim to become an application that is able to support government policy, especially in developing teacher competence in Indonesia so that positive impact for the progress of education in Indonesia (Sasmoko et al., 2017). However, if studied further, this application can also be utilized as a real time system for the teacher itself. The speed of application in assessing the condition of teachers in real time will help teachers in mapping their current condition so that know how to choose and do the right program in accordance with priority conditions that must be improved.

Concept of Real Time System was first introduced in the early 90's as a new concept and approach to processing information (Benvensite and Berry, 1991; Shin and Ramanathan, 1994). The operation of real time system is closely related to dynamic changes and is inseparable to asynchronous programming. Without using a real time system, the whole line of procedure must be re-executed every time the input is changed. This process is known as synchronous programming. When the system is executed in a real time system, dedicated events are deterministic, independent from the main procedure, and is able to compute its own data streams. It enables a real-time change in a system's output, without having to redo all its own operation. Therefore, real time system is very suitable for event-driven application 
(Bainomugisha et al., 2013). This research tries to conduct real time study system and design for Indonesian Teacher Engagement Index Application.

\section{Related Work}

Real time system is very powerful the development and implementation is combined with embedded system. A recent research done by Khalid et al. (2018) implements real time system with remote monitoring to treat patients with chronic heart disease. In a field of national defense, real time system is used to analyze thermal footprint data obtained by drone (Amanatiadis et al., 2018). In commercial and industrial based use, a real time monitoring system can be used to monitor carbon monoxide concentration, and the finished product can be used in many field of opportunities, starting from environmental control, to detecting biological threat (Yang et al., 2015).

The usage of platform for real time system implementation is visibly unlimited. It can be implemented in a desktop application, web application, and mobile application. In a condition where time is much more valuable than money, a real time system truly fulfils the essential demands for modern society. Build upon the powerful nature of the system, and limitless opportunity to establish a newer and a more innovative architecture in each platform, real time system has really became the must-do requirement for any corresponding field.

The application of real time system in desktop uses ranges from a real time virtualized operating system, real time desktop sharing, to real time energy management system (Castelli et al., 2016; Liang et al., 2017; Teplov et al., 2016). Although the growing trend of development in a modern days is noticeably shifted to ubiquitous computing, desktop computing is still a to-go platform for services with efficiency in mind. Since real time computing effectively manages computing component and processing time adequately, it is very suitable to be implemented in desktop software.

One of the biggest challenge in a term of real time system implementation is to apply it in a web-based application. Web platform always has a hard time processing real time information, mostly limited to its nature of interconnected network, which makes the communication between server and client very difficult to handle, and requires a lot of computing power. For web development, AJAX (Asynchronous JavaScript \& $\mathrm{XML}$ ) is one of the framework used for real time computing - or more commonly described by web developers as Asynchronous Computing. The implementation of AJAX enables the content of web pages to change dynamically, as opposed to the conventional way of reloading the whole page (Ullman and Dykes, 2007).

Real time system development in Android is not as difficult as Web Application implementation, yet not as easy as Desktop Application implementation. In Android, real time system is closely related to Firebase-Database, because of the extra service layer added on Firebase (Christina, 2018). Still, one of the biggest challenges in real time Android application is to choose the high performance programming language. In an online real time system, the challenge is bigger due to the dependency on internet / network connection to fetch the real time data. An example of practical field of use for real time system in Android is the real time home monitoring system - or popularly known as Smart Houses. Smart Houses utilizes the power of internet connection and real time system to produce a home automation and monitoring system, with features like remote light switches, temperature sensors, humidity sensors, and up to intrusion detection (Bhoyar, 2015; Kumar, 2014). Some offline application implementations on Android ranges from utility applications such as phone security \& privacy monitoring and location tracking, to task-specific applications, such as speech rate monitor to virtual fitting room application (Aharonson et al., 2017; Chandra et al., 2018; Heuser et al., 2016; Sarkar, 2017).

\section{METHOD}

This study used the early stages in the neuroresearch method, ie exploratory research (Sasmoko et al., 2018). With the existing applications, researchers try to do the review through various literature review to understand the concept of real time system more specifically. Eksploratory on real time system will be utilized in the process of development and optimization of ITEI application so as to give added value and benefit which more optimal for user that is teacher in Indonesia. The purpose of exploratory research is to develop hypotheses rather than testing them. This study tries to formulate a problem to investigate more deeply so as to develop a more precise hypothesis (Kothari, 2004). To develop the precise hypothesis requires an expert system in order that the process and results are carried out in accordance with original circumstances (Udjaja, 2018; Udjaja et al., 2018). Subsequently added with user interface and user experience that is easy to understand so users can understand the process and results of profiling which is conducted (Kristiadi et al., 2017; Udjaja, 2018).

\section{RESULT AND ANALYSIS}

The result of research is real-time system design for Indonesian Teacher Engagement Index (ITEI) application. After the teacher access through ITEI application, the application not only generates the chart as a result of the teacher's measurement of the condition of engagement inside him. But more than that, the results will result in profiling teachers more specifically with a complete picture relating to the dimensions or indicators that must immediately require follow-up. So that the at that time the also the teacher will be able to see an aspect that there is in him that require program immediately in 
order to be more optimal in work which eventually will have an impact on the improvement of teacher performance itself.

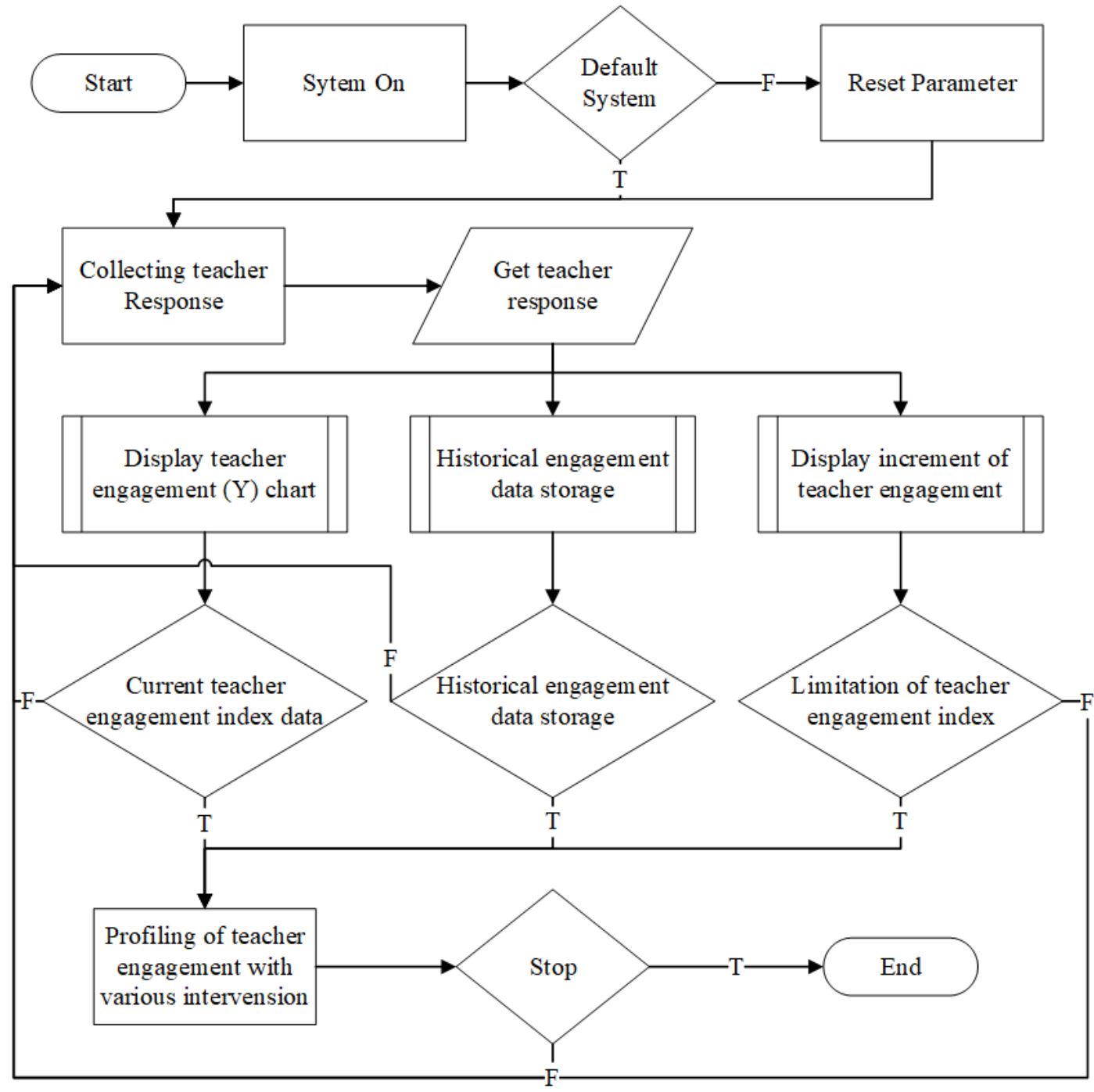

Figure 1: Design Real Time Systemfor ITEI Apps

\section{DISCUSSIONS AND CONCLUSSIONS}

The results of the study produced a real-time system design. This design is an additional scheme in an effort to continue to maximize the value and function of ITEI applications for teachers as users. As a teacher who developed in the century coloured by technological developments, it is time for teachers to be able to improve their competence and self-performance independently. With the existence of an Android-based ITEI application that is easily accessible, the teacher can conduct an assessment easily Wusing their mobile phone and at that time the teacher is able to see their condition in detail, which is related to the psychological condition of the teacher in real terms from the perspective of positive psychology, the condition of the teacher's contribution for education seen from the perspective of positive education; the condition of the teacher's performance at that time, the condition of the teacher related to the value of being a teacher in Indonesia, the condition of the competence possessed by the teacher and the condition of the teacher's leadership itself (Sasmoko et al., 2017; Sasmoko et al., 2018; Sasmoko et al., 2018).

Explanation of these dimensions can be seen in table 1 (Sasmoko et al., 2017; Sasmoko et al., 2018). 
Table 1: Strength and Limitation in Website Pattern Design

\begin{tabular}{|c|c|c|}
\hline Dimension & $\begin{array}{c}\text { Type of } \\
\text { Dimension }\end{array}$ & Indicator \\
\hline \multirow{6}{*}{1} & \multirow{6}{*}{$\begin{array}{l}\text { Positive } \\
\text { Psychology }\end{array}$} & Wisdom and Knowledge \\
\hline & & Courage \\
\hline & & Humanity \\
\hline & & Justice \\
\hline & & Temperance \\
\hline & & Transcendence \\
\hline \multirow{6}{*}{2} & \multirow{6}{*}{$\begin{array}{l}\text { Positive } \\
\text { Education }\end{array}$} & Positive Emotion \\
\hline & & Positive Engagement \\
\hline & & Positive Accomplishment \\
\hline & & Positive Purpose \\
\hline & & Positive Relationship \\
\hline & & Positive Health \\
\hline \multirow{4}{*}{3} & \multirow{4}{*}{$\begin{array}{l}\text { Teacher } \\
\text { Performance }\end{array}$} & Task Performance \\
\hline & & Contextual Performance \\
\hline & & $\begin{array}{l}\text { Counterproductive } \text { Work } \\
\text { Behavior }\end{array}$ \\
\hline & & Adaptive Performance \\
\hline 4 & $\begin{array}{l}\text { Nationality } \\
\text { Character }\end{array}$ & $\begin{array}{l}\text { Character of foundational } \\
\text { philosophical theory of } \\
\text { Indonesian state }\end{array}$ \\
\hline \multirow{4}{*}{5} & \multirow{4}{*}{$\begin{array}{l}\text { Teacher } \\
\text { Competences }\end{array}$} & Pedagogic Competence \\
\hline & & Personality Competence \\
\hline & & Social Competence \\
\hline & & Professional Competence \\
\hline \multirow{7}{*}{6} & \multirow{7}{*}{$\begin{array}{l}\text { Nationalism } \\
\text { Leadership } \\
\text { Engagement }\end{array}$} & $\begin{array}{l}\text { Have a leadership spirit } \\
\text { that represents the } \\
\text { interests of Indonesia as a } \\
\text { whole }\end{array}$ \\
\hline & & $\begin{array}{l}\text { Have a positive perception } \\
\text { of the region and fight for } \\
\text { the integrity of Indonesia }\end{array}$ \\
\hline & & Trustworthy educators \\
\hline & & $\begin{array}{l}\text { Have the competence in } \\
\text { managing } \\
\text { students }\end{array}$ \\
\hline & & $\begin{array}{l}\text { Be an example of building } \\
\text { the paradigm of students } \\
\text { in seeing their region as an } \\
\text { integral part of Indonesia }\end{array}$ \\
\hline & & $\begin{array}{l}\text { Able to motivate students } \\
\text { to prioritize national } \\
\text { interests }\end{array}$ \\
\hline & & $\begin{array}{l}\text { Creative and innovative in } \\
\text { dealing with problems } \\
\text { with the principle of } \\
\text { Indonesian stability }\end{array}$ \\
\hline
\end{tabular}

\section{ACKNOWLEDGMENTS}

This work is partially supported by Ministry of Research, Technology, and Higher Education of the Republic of Indonesia and The Ministry of Education and Culture of the Republic of Indonesia. The authors also gratefully acknowledge the helpful comments and suggestions of the reviewers, which have improved the presentation.

\section{REFERENCES}

[1] Aharonson, V., Aharonson, E., Raichlin-Levi, K., Sotzianu, A., Amir, O., \& Ovadia-Blechman, Z. 2017. A real-time phoneme counting algorithm and application for speech rate monitoring. Journal of fluency disorders, 51, 60-68.

[2] Amanatiadis, A., Bampis, L., Karakasis, E. G., Gasteratos, A., \& Sirakoulis, G. 2018. Real-time surveillance detection system for medium-altitude long-endurance unmanned aerial vehicles. Concurrency and Computation: Practice and Experience, 30(7), e4145.

[3] Bainomugisha, E., Carreton, A. L., Cutsem, T. V., Mostinckx, S., \& Meuter, W. D. 2013. A survey on reactive programming. ACM Computing Surveys (CSUR), 45(4), 52.

[4] Benveniste, A., \& Berry, G. 1991. The synchronous approach to reactive and real-time systems. Proceedings of the IEEE, 79(9), 1270-1282.

[5] Bhoyar, M. R. 2015. Home automation system via internet using Android phone. InternationalJournal of Research in Science and Engineering. CSE Department, JDIET, Yavatmal, 6.

[6] Castelli, G., Hackett, M., Howard, M. Q., Jones, L. E., Shung, H. S., \& Brand, H. D. 2016. Energy management system that provides a real time assessment of a potentially compromising situation that can affect a utility company. U.S. Patent No. 9,367,935. Washington, DC: U.S. Patent and Trademark Office.

[7] Chandra, R. N., Febriyan, F., \& Rochadiani, T. H. 2018. Single Camera Body Tracking for Virtual Fitting Room Application. In Proceedings of the 2018 10th International Conference on Computer and Automation Engineering (pp. 17-21). ACM.

[8] Christina, Farr. 2018. Firebase's scalable backend makes it '10 times easier' to build apps. VentureBeat.

[9] Heuser, S., Negro, M., Pendyala, P. K., \& Sadeghi, A. R. 2016. DroidAuditor: Forensic Analysis of Application-Laver Privilege Escalation Attacks on Android (Short Paper). In International Conference on Financial Cryptography and Data Security (pp. 260268). Springer, Berlin, Heidelberg.

[10] Kalid, N., Zaidan, A. A., Zaidan, B. B., Salman, O. H., Hashim, M., Albahri, O. S., \& Albahri, A. S. 2018. Based on Real Time Remote Health Monitoring Systems: A New Approach for Prioritization "Large Scales Data" Patients with Chronic Heart Diseases Using Body Sensors and Communication Technology. Journal of medical systems, 42(4), 69.

[11] Kothari, C. R. 2004. Research methodology: Methods and techniques. New Age International.

[12] Kristiadi, D. P., Udjaja, Y., Supangat, B., Prameswara, R. Y., Warnars, H. L. H. S., Heryadi, Y., \& Kusakunniran, W. 2017. The effect of UI, UX and GX on video games. In Cybernetics and Computational Intelligence (CyberneticsCom), 2017 IEEE International Conference on (pp. 158-163). IEEE.

[13] Kumar, S. 2014. Ubiquitous smart home system using android application. arXiv preprint arXiv:1402.2114.

[14] Liang, H., Li, M., Xu, J., Hu, W., Pei, X., Jia, X., \& Song, Y. 2017. vmOS: A virtualization-based, secure desktop system. Computers \& Security, 65, 329-343. 
[15] Manalu, S. R., Sasmoko, Permai, S. D., Widhoyoko, S. A., \& Indrianti, Y. 2018. Designing indonesian teacher engagement index (itei) applications based on android. In Journal of Physics: Conference Series (Vol. 978, No. 1, p. 012005). IOP Publishing.

[16] Sarkar, S. K. 2017. Cost and Energy Efficient Real Time Location Tracking Android Application Framework (Doctoral dissertation, East West University).

[17] Sasmoko, Abbas, B. S., Indrianti, Y., \& Widhoyoko, S. A. 2018. Indonesian teacher engagement index: a rasch model analysis. In IOP Conference Series: Materials Science and Engineering (Vol. 296, No. 1, p. 012027). IOP Publishing.

[18] Sasmoko, Doringin, F., Indrianti, Y., Goni, A. M., \& Ruliana, P. 2018. Indonesian Teacher Engagement Index (ITEI): An Emerging Concept of Teacher Engagement in Indonesia. In IOP Conference Series: Materials Science and Engineering(Vol. 306, No. 1, p. 012119). IOP Publishing.

[19] Sasmoko, INDRIANTI, Y., PERMAI, S. D., \& MANALU, S. R. 2018. APPLYING INDONESIAN TEACHER ENGAGEMENT INDEX (ITEI) APPS: SELF-DIAGNOSTIC APPS FOR TEACHERS IN INDONESIA. ICIC express letters. Part B, Applications: an international journal of research and surveys, 9(4), 273-280.

[20] Sasmoko, Muqsith, A. M., Widhyatmoko, D., Indrianti, Y., \& Khan, A. 2017. Indonesian teacher engagement index (ITEI): Decision support system for education. In Cyber and IT Service Management (CITSM), 2017 5th International Conference on (pp. 1-5). IEEE.

[21] Sasmoko, Muqsith, A. M., Widhyatmoko, D., Indrianti, Y., \& Khan, A. 2017). Indonesian teacher engagement index (ITEI): Decision support system for education. In Cyber and IT Service Management (CITSM), 2017 5th International Conference on (pp. 1-5). IEEE.

[22] Sasmoko, Noerlina, INDRIANTI, Y., PERMAI, S. D., \& MANALU, S. R. (2018). APPLYING INDONESIAN TEACHER ENGAGEMENT INDEX (ITEI) APPS: SELF-DIAGNOSTIC APPS FOR TEACHERS IN INDONESIA. ICIC express letters. Part B, Applications: an international journal of research and surveys, 9(4), 273-280.

[23] Sasmoko, Wijaksono, S., Indrianti, Y., \& Widhoyoko, S. A. 2018. The determinants of the socio-cultural ecology architect's competence. In IOP Conference Series: Earth and Environmental Science (Vol. 195, No. 1, p. 012097). IOP Publishing.

[24] Sasmoko, Y. I., Khan, A., Nurkamto, J., \& Harsoyo, Y. 2017. CONSTRUCT THEORETICAL: INDONESIAN TEACHER ENGAGEMENT INDEX (ITEI). Man In India, 97(19), 91-97.

[25] Shin, K. G., \& Ramanathan, P. 1994. Real-time computing: A new discipline of computer science and engineering. Proceedings of the IEEE, 82(1), 6-24.

[26] Teplov, I., Skurikhin, A., Huck, P., \& Fedotov, A. 2007. Method of sharing a desktop with attendees of a realtime collaboration. U.S. Patent No. 7,222,305. Washington, DC: U.S. Patent and Trademark Office.

[27] Udjaja, Y., Guizot, V. S., \& Chandra, N. 2018. Gamification for Elementary Mathematics Learning in
Indonesia. International Journal of Electrical and Computer Engineering (IJECE), 8(6).

[28] Udjaja, Y. 2018. Android Application for Detection of Skin Cancer Using Expert System. Social Economics and Ecology International Journal (SEEIJ), 1(2), 54-61.

[29] Udjaja, Y. 2018. Gamification Assisted Language Learning for Japanese Language Using Expert Point Cloud Recognizer. International Journal of Computer Games Technology, 2018.

[30] Ullman, C., \& Dykes, L. (2007). Beginning Ajax. John Wiley \& Sons.

[31] Yang, J., Zhou, J., Lv, Z., Wei, W., \& Song, H. (2015). A real-time monitoring system of industry carbon monoxide based on wireless sensor networks. Sensors, 15(11), 29535-29546. 